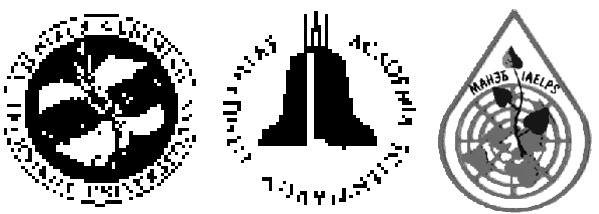

\title{
INVESTIGATION INTO BIOLOGICAL NUTRIENT REMOVAL FROM WASTEWATER
}

\author{
Giedrė Vabolienė, Algirdas Bronislovas Matuzevičius \\ Dept of Water Supply and Management, Vilnius Gediminas Technical University, \\ Sauletekio al.11,LT-10223 Vilnius-40,Lithuania.E-mail: vk@ap.vtu.lt
}

Received 23 May 2005; accepted 18 Sept 2005

\begin{abstract}
Nitrogen and phosphorus removal is necessary to avoid eutrophication of water bodies when treated wastewater is outlet to slowly flowing water bodies or recycled as technological water. The "BioBalance" technology as the latest way of nitrogen and phosphorus removal was applied at Utena Wastewater Treatment Plant. Composition of wastewater has an impact on biological phosphorus removal, particularly the ratio of biochemical oxygen demand and total phosphorus $\left(\mathrm{BOD}_{7} /\right.$ Total-P) in wastewater after mechanical treatment. Nitrates in the anaerobic zone can have a negative effect on biological phosphorus removal. Consequently, it is necessary to evaluate the impact of the mentioned factors on biological nitrogen and phosphorus removal.

Biological nitrogen and phosphorus removal was evaluated and compared by using the "BioBalance" technology for biological nitrogen and phosphorus removal and technology before reconstruction during this investigation. The correlation regressive analysis of the biochemical oxygen demand and total phosphorus $\left(\mathrm{BOD}_{7} /\right.$ Total-P) after mechanical treatment and the total phosphorus concentration in the effluent was evaluated. The correlation regressive analysis of nitrates in an anaerobic zone on the aeration tank and the efficiency of phosphorus removal was also evaluated.
\end{abstract}

Keywords: biological nitrogen removal, biological phosphorus removal, biological active potential (BAP), ratio of biochemical oxygen demand and total phosphorus $\left(\mathrm{BOD}_{7} /\right.$ Total-P), nitrate, phosphate

\section{Introduction}

Utena Wastewater Treatment Plant was renovated in 1999. The most advanced "BioBalance" technology was applied at Utena Wastewater Treatment Plant where nitrogen is removed in a nitrification/denitrification tank, and the anaerobic zone is equipped before the nitrification/denitrification tank of the biological phosphorus removal. Composition of wastewater has an impact on biological phosphorus removal, particularly the ratio of biochemical oxygen demand and total phosphorus $\left(\mathrm{BOD}_{7} /\right.$ Total-P) in wastewater after mechanical treatment [1-3].

Nitrates in the anaerobic zone can have a negative effect on biological phosphorus removal. Volatile fatty acids are used for denitrification of nitrates. Volatile fatty acids could be assimilated by the acinetobacter [4-6].

Following the reasons mentioned above, the impact on biological nitrogen and phosphorus removal needs to be evaluated.

The aim of the work was to evaluate the biological nitrogen and phosphorus removal efficiency using the "BioBalance" technology at Utena Wastewater Treatment
Plant. Biological nitrogen and phosphorus removal was evaluated and compared by using the "BioBalance" technology for biological nitrogen and phosphorus removal and technology before reconstruction during this investigation. The correlation regressive analysis of the biochemical oxygen demand and total phosphorus $\left(\mathrm{BOD}_{7} /\right.$ Total-P) after mechanical treatment and the total phosphorus concentration in the effluent was evaluated. The correlation regressive analysis of nitrates in the anaerobic zone on the aeration tank and the efficiency of phosphorus removal were also evaluated.

\section{Investigation object}

After reconstruction the capacity of Utena Wastewater Treatment Plant was on the average $10000 \mathrm{~m}^{3} / \mathrm{d}$, wastewater pollution treatment: biochemical oxygen demand $\left(\mathrm{BOD}_{7}\right)-9 \mathrm{mg} / \mathrm{l}$, suspended solids $-12 \mathrm{mg} / \mathrm{l}$, total phosphorus $-1,2 \mathrm{mg} / \mathrm{l}$, total nitrogen $-7 \mathrm{mg} / \mathrm{l}$.

The "BioBalance" technology is based on the control system of a new equipment - NADH fluorescensor which makes it possible to control directly biological pro- 
cesses. The control purpose is to supply a minimum air quantity to assure a constant oxygen amount necessary for biological processes.

The "BioBalance Symbio" technology for nitrogen removal is based on the active sludge technology with simultaneous (synchronous) denitrification. There is no special separation between the nitrification and denitrification zones in the aeration tank. At the same time denitrification is carried out during nitrification in the aeration tank, and there are zones without dissolved oxygen (anoxic zones) [7]. Consequently, the nitrification and denitrification and purification of organic matter take in the place at the same time. Nitrification takes place in the outermost section of sludge floccules, while denitrification takes place closer to the centre of sludge floccules. This is illustrated in Fig 1.

Commonly existing co-ferments functioning as suppliers of hydrogen and electrons are nicotinamideadeninedinucleotide $\mathrm{NAD}^{+}$.

During the processes of metabolism co-ferments $\mathrm{NADH}$ and NADPH are produced in all the microorganisms. NAD $(\mathrm{P}) \mathrm{H}$ quantity in the micro- organisms produced depends on their activity. The above mentioned activity depends on the existing sludge loads supplied in the form of nutritious matter. It means that, for example, NAD $(\mathrm{P}) \mathrm{H}$ quantity will remain stable under the conditions of a constant quantity of nutritious matter supplied to an active sludge system, constant load and sludge activity. The sludge activity and at the same time NAD $(\mathrm{P}) \mathrm{H}$ production increase gradually with increase of the sludge load because of a more intensive supply of nutritious matter [8]. Differently, NAD(P)H production decreases during decrease of the nutritious matter supply. During the investigation the linear dependence was determined [9].

$\mathrm{NADH}$ fluorecsensor is a fluoremeter installed in a stainless steel case and emitting $340 \mathrm{~nm}$ shafts through the quartz glass. The light from the instrument penetrates the microorganisms and detects the NADH compound which, when illuminated, emits $460 \mathrm{~nm}$ shafts, and NADH sensor registers them. NADH is constantly converted from the

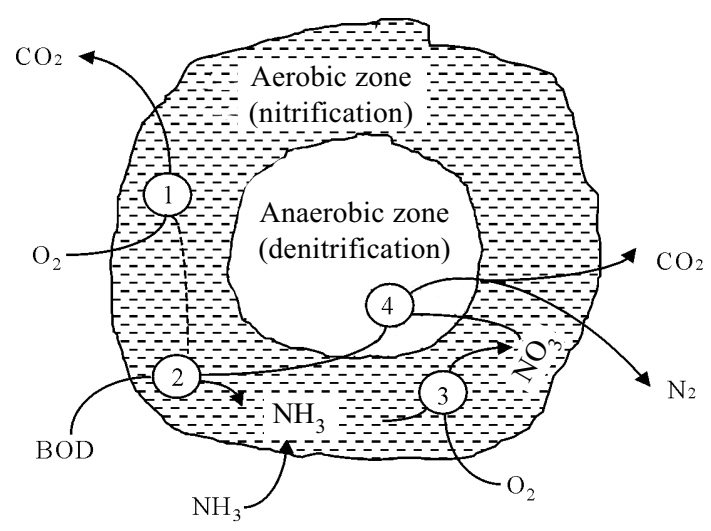

Fig 1. Important conversion processes in sludge floccules: 1 - (oxygen) respiration, 2 - ammonification, 3 - nitrification, 4 - nitrate respiration (denitrification) oxidator NAD into the reducing agent NADH in the active sludge [10]. The fluorecsensor fixes only NADH that gives information on how much energy the microorganisms possess. The information on the energy is defined as the biological active potential (BPA). By monitoring BPA it is possible to control the biological processes [10].

Three aeration tanks are used in parallel. The intake part in each aeration tank is used as an anaerobic zone for biological phosphorus removal. The remaining part is used as an aeration tank (Fig 2).

Accumulating polyphosphates microorganisms are growing in the anaerobic zone. They can accumuliate a large quantity of phosphates in their own cells.

NADH fluorescensor controls denitrification and nitrification processes according to the sludge activity in a single aeration tank (Fig 2). Ammonia is oxidized to nitrates by nitrifying bacteria during the nitrification phase. Nitrates are reduced to molecular nitrogen $\left(\mathrm{N}_{2}\right)$ by denitrifying bacteria during the denitrification phase. These processes are carried out periodically. Organic matter is oxidized bacterially during both the nitrification and denitrification phases, with oxygen and nitrates, respectively, as the oxidizing agents and phosphorus are absorbable with special microorganisms. NADH fluorescensor and oxygen meter are mounted on each aeration tank.

Low oxygen concentrations $(0,1-0,5 \mathrm{mg} / \mathrm{l})$ were kept for denitrification to proceed, and higher oxygen concentrations $(0,5-1 \mathrm{mg} / \mathrm{l})$ were maintained for nitrification processes to proceed periodically.

If an organic load decreases, oxygen concentration should be decreased to avoid a "sloop" in the process that would cause an increase of ammonium nitrogen concentration in the aeration tank. Conditions to carry out nitrification were approximately $2-3$ hours, after that 2-2,5 hours were spent to carry out the denitrification process.

\section{Investigation methodology}

Investigation was carried out at Utena Wastewater Treatment Plant during a one-year period in 2004. Data

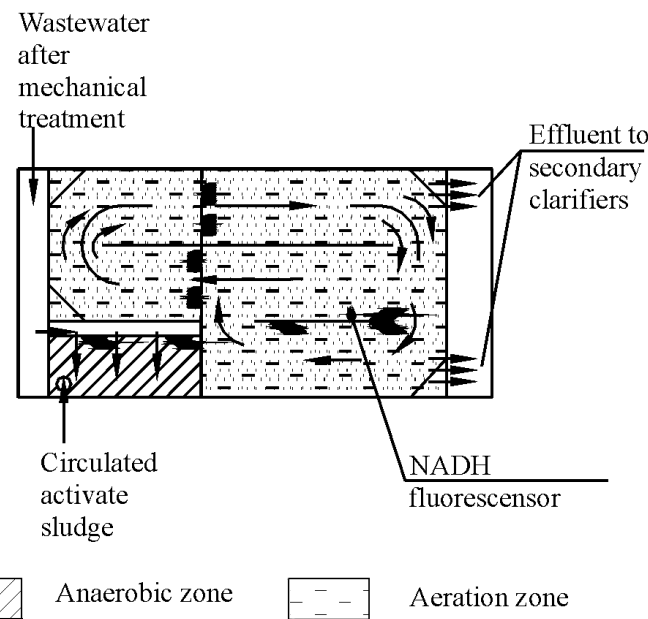

Fig 2. Basic scheme of aeration tank 
about nitrogen and phosphorus removal before reconstruction were also gathered. Two aeration tanks were used for the biological wastewater treatment at Utena Wastewater Treatment Plant. Once a week biochemical oxygen demand $\left(\mathrm{BOD}_{7}\right)$, total phosphorus and total nitrogen concentration in wastewater after the mechanical treatment and in the effluent were measured. Total nitrogen was estimated adding Kjeldahl nitrogen to nitrites and nitrates. Nitrate concentration in the anaerobic zone of the aeration tank and phosphates in the aeration zone were measured.

The data of 52 experiments were statistically estimated. Experimental data are statistically faithful, if the likelihood is from $92,5 \%$ to $97,5 \%$. For the gathered data, checking of statistical faithfulness was performed: arithmetical averages of the gathered data $(\mathrm{X})$, parameter of Stjudent repartition $\left(\mathrm{t}_{95}\right)$, standard deflection $(\delta)$. Reservation of statistically faithful data was checked: $\left[\mathrm{X}_{\mathrm{i}}-\mathrm{X}\right]<2 \delta$ [11]. The data the dissonant reservation of which from statistically faithful ones was eliminated and the count was repeated. The standard statistical estimation error of the arithmetic average was approximately $12 \%$.

\section{Investigation results}

An aeration tank with active sludge was used for biological wastewater treatment before reconstruction. Using this technology for biological wastewater treatment, the concentration of total nitrogen and total phosphorus found was higher than an allowable norm because nitrogen and phosphorus were used only by microorganisms of active sludge in biochemical processes.

The experimental data show that total nitrogen (Total-N) and total phosphorus (Total-P) decreased in the effluent after reconstruction and was not higher than an allowable norm (Table 1).

The evaluation of Utena Wastewater Treatment Plant before and after the reconstruction shows that $32 \%$ of total nitrogen and $10 \%$ of total phosphorus were removed before reconstruction, and $84,6 \%$ of total nitrogen and up to $97 \%$ of total phosphorus were removed using "Biobalance" technology after reconstruction (Figs 3, 4).

The ratio $\mathrm{BOD}_{5} /$ Total-P shows possibility for biological phosphorus removal. The higher this ratio, the more efficient biological phosphorus removal processes. Information sources show that biological phosphorus removal can be carried out efficiently, when the ratio $\mathrm{BOD}_{5} /$ Total$\mathrm{P}$ is higher than 20 [1]. The ratio $\mathrm{BOD}_{7} /$ Total-P in wastewater after mechanical treatment was from 9 to 47 in 2004 (Table 2).

Table 1. Comparison of nutrient concentrations in effluent before and after WWTP reconstruction following requirements

\begin{tabular}{|c|c|c|c|}
\hline Pollution & $\begin{array}{c}\text { Nutrient in } \\
\text { effluent } \\
\text { before recons- } \\
\text { truction, mg/l }\end{array}$ & $\begin{array}{c}\text { Nutrient in } \\
\text { effluent after } \\
\text { recons- } \\
\text { truction, } \mathrm{mg} / \mathrm{l}\end{array}$ & $\begin{array}{c}\text { Allowable } \\
\text { nutrient } \\
\text { concentra- } \\
\text { tions, mg/l }\end{array}$ \\
\hline Total-P & $2,9 \div 6,2$ & $0,23 \div 2,2$ & 2 \\
\hline Total-N & $10 \div 24$ & $5,6 \div 10$ & 15 \\
\hline
\end{tabular}

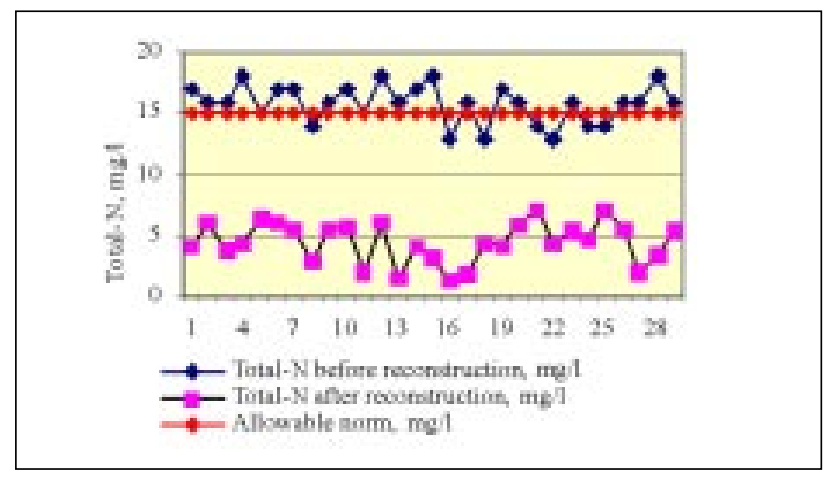

Fig 3. Total nitrogen in effluent before and after reconstruction

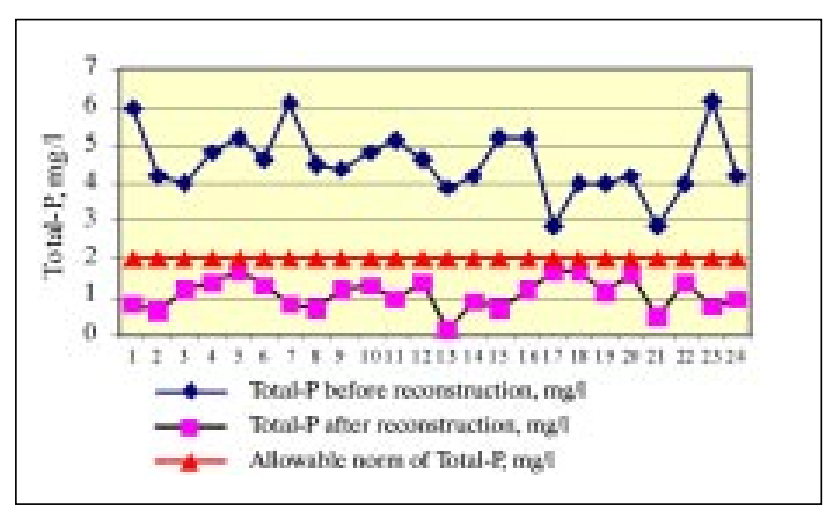

Fig 4. Total phosphorus in effluent before and after reconstruction

When the ratio $\mathrm{BOD}_{7} /$ Total-P of wastewater after mechanical treatment was from 9 to 15 , the efficiency of biological phosphorus removal was reduced. The concentration of total phosphorus in the effluent was from 1,4 to $2,2 \mathrm{mg} / \mathrm{l}$. When the ratio $\mathrm{BOD}_{7} /$ Total-P was from 15 to 20 , phosphorus was removed efficiently. The concentration of total phosphorus in the effluent was from 0,23 to $1,2 \mathrm{mg} / 1$. When the ratio $\mathrm{BOD}_{7} /$ Total-P was over 20, phosphorus was removed efficiently too. The concentration of total phosphorus in the effluent was from 0,24 to $0,9 \mathrm{mg} / \mathrm{l}$.

The regressive correlation analysis of statistically faithful data (the ratio $\mathrm{BOD}_{7} /$ Total-P and total phosphorus in the effluent in 2004) was provided for estimating dependence between the efficiency of phosphorus removal and the ratio $\mathrm{BOD}_{7} /$ Total-P.

The regressive correlation analysis of these data shows dependence of phosphorus concentration in the effluent on the ratio $\mathrm{BOD}_{7} /$ Total-P. The polynomial regression model

Table 2. Ratio $\mathrm{BOD}_{7} /$ Total-P and total phosphorus in effluent in 2004

\begin{tabular}{|c|c|c|c|}
\hline $\begin{array}{c}\text { Ratio } \\
\mathrm{BOD}_{7} / \text { Total }-\mathrm{P}\end{array}$ & $\begin{array}{c}\text { Average of } \\
\mathrm{BOD}_{7} / \text { Total-P, } \\
\mathrm{mg} / \mathrm{l}\end{array}$ & $\begin{array}{c}\text { Total-P in } \\
\text { effluent, } \mathrm{mg} / \mathrm{l}\end{array}$ & $\begin{array}{c}\text { Average of } \\
\text { Total-P in } \\
\text { effluent, } \mathrm{mg} / \mathrm{l}\end{array}$ \\
\hline $9 \div 15$ & 11 & $1,4 \div 2,2$ & 1,88 \\
\hline $15 \div 20$ & 18 & $0,23 \div 1,2$ & 0,75 \\
\hline $20 \div 47$ & 26 & $0,24 \div 0,99$ & 0,64 \\
\hline
\end{tabular}




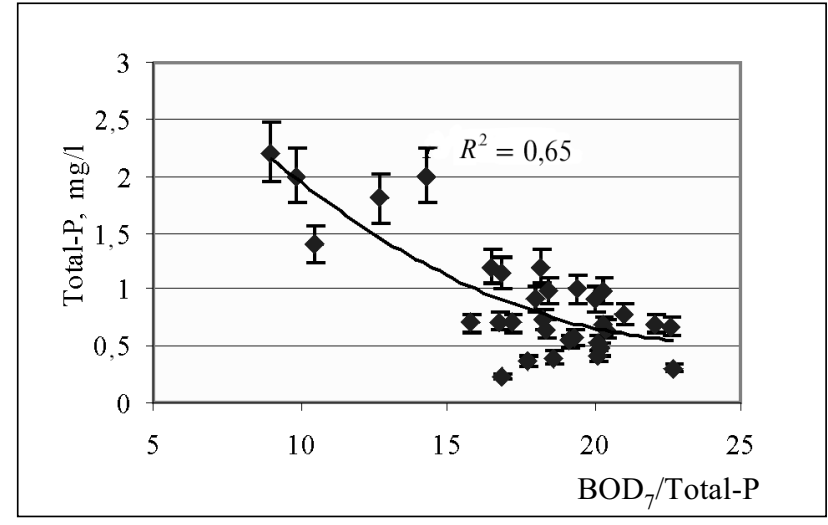

Fig 5. Dependence of total phosphorus in effluent on ratio $\mathrm{BOD}_{7} /$ Total-P

is suitable for the obtained results (Fig 5). The model correlation index $R^{2}=0,65$.

The model of the polynomial regression is obtained:

$$
Y=0,0072 x^{2}-0,3449 x+4,6735,
$$

where

$Y$ - phosphorus concentration in effluent, $\mathrm{mg} / \mathrm{l}, x$ - ratio $\mathrm{BOD}_{7} /$ Total-P.

Nitrates in the anaerobic zone have a negative effect on biological phosphorus removal. Volatile fatty acids are used for denitrification of nitrates. Volatile fatty acids could be assimilated by the acinetobacter. As a consequence, the efficiency of biological phosphorus removal decreases. It was estimated that phosphorus is removed efficiently, when the concentration of nitrates in the anaerobic zone is not higher than $2 \mathrm{mg} / \mathrm{l}$ [12].

Measurement of nitrate concentration in the anaerobic zone and phosphate concentration in the aeration zone of the aeration tank at Utena Wastewater Treatment Plant was performed. The purpose was to estimate the effect of nitrates in the anaerobic zone on biological phosphorus removal. The obtained parameters show that, when the concentration of nitrates in the anaerobic zone was over $1 \mathrm{mg} / \mathrm{l}$, the concentration of phosphates in the aerobic zone decreased and was from 0,25 to $1,6 \mathrm{mg} / \mathrm{l}$. Consequently, the efficiency of biological phosphorus removal was reduced. However, there were only several occasions. Other factors had an impact on the efficiency of biological phosphorus removal. Commonly the concentration of nitrates in the anaerobic zone was from 0,22 to $1 \mathrm{mg} / 1$, and then phosphates in the aerobic zone were from 0,013 to $0,41 \mathrm{mg} / 1$ (Table 3). Consequently, nitrates in the anaerobic zone cannot have a negative effect on biological phosphorus removal, when the „Biobalance“ technology is used.

The regressive correlation analysis of these data shows the dependence of phosphate concentration in the aeration zone on nitrate concentration in the anaerobic zone. The polynomial regression model is suitable following the received results. The model correlation index is, respectively, $R^{2}=0,95$ and $R^{2}=0,94$ for the first and second aeration tanks (Figs 6,7).
Table 3. Concentration of nitrates and phosphates in different zones of two aeration tanks in 2004

\begin{tabular}{|c|c|c|c|}
\hline $\begin{array}{c}\text { Amount of } \\
\text { nitrates in } \\
\text { anaerobic } \\
\text { zone, } \mathrm{mg} / \mathrm{l}\end{array}$ & $\begin{array}{c}\text { Average of } \\
\text { nitrates in } \\
\text { anaerobic } \\
\text { zone, } \mathrm{mg} / \mathrm{l}\end{array}$ & $\begin{array}{c}\text { Amount of } \\
\text { phosphates in } \\
\text { aeration } \\
\text { zone, } \mathrm{mg} / \mathrm{l}\end{array}$ & $\begin{array}{c}\text { Average of } \\
\text { phosphates, } \\
\mathrm{mg} / \mathrm{l}\end{array}$ \\
\hline \multicolumn{4}{|c|}{ The first aeration tank } \\
\hline $2 \div 1,1$ & 1,68 & $0,6 \div 1,6$ & 1,25 \\
\hline $0,94 \div 0,41$ & 0,58 & $0,021 \div 0,2$ & 0,09 \\
\hline $0,4 \div 0,24$ & 0,32 & $0,0001 \div 0,29$ & 0,09 \\
\hline \multicolumn{4}{|c|}{ The second aeration tank } \\
\hline $1,8 \div 1,1$ & 1,35 & $0,37 \div 1,4$ & 0,8 \\
\hline $0,73 \div 0,41$ & 0,51 & $0,015 \div 0,24$ & 0,09 \\
\hline $0,4 \div 0,22$ & 0,32 & $0,013 \div 0,22$ & 0,08 \\
\hline
\end{tabular}

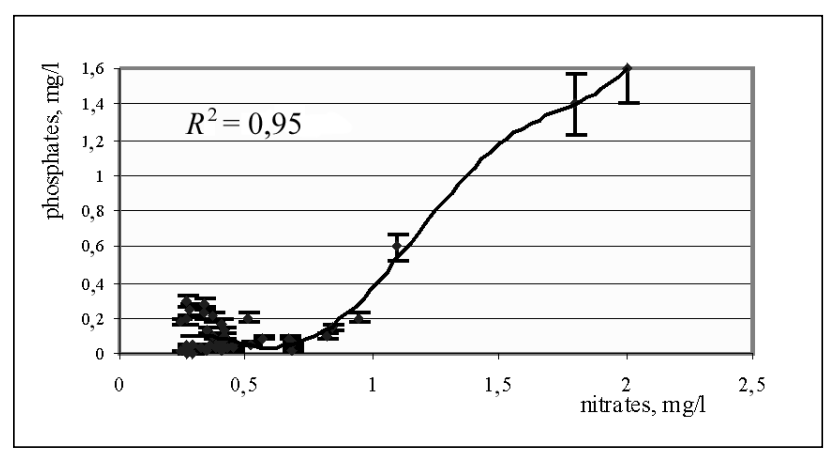

Fig 6. Dependence of phosphate concentration in aeration zone on nitrate concentration in anaerobic zone of the first aeration tank

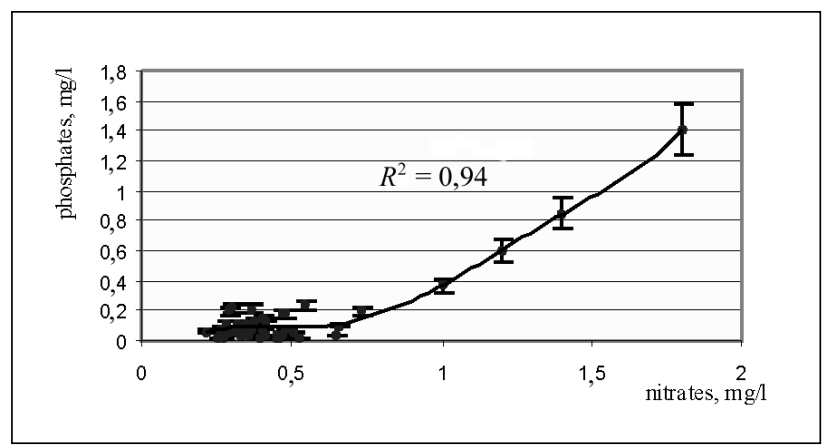

Fig 7. Dependence of phosphate concentration in aeration zone on nitrate concentration in anaerobic zone of the second aeration tank

The model of the polynomial regression was obtained - for the first aeration tank:

$$
\begin{aligned}
Y= & 1,676 x^{5}-9,4169 x^{4}+18,696 x^{3}- \\
& 15,112 x^{2}+4,9902 x-0,4655
\end{aligned}
$$

for the second aeration tank:

$$
\begin{aligned}
Y= & 1,2069 x^{5}-6,1764 x^{4}+11,483 x^{3}- \\
& 8,8168 x^{2}+2,9453 x-0,2688
\end{aligned}
$$

where

$Y$ - phosphate concentration in aeration zone, $\mathrm{mg} / \mathrm{l}, x-\mathrm{ni}$ trate concentration in anaerobic zone, $\mathrm{mg} / \mathrm{l}$. 


\section{Conclusions}

1. Evaluating Utena Wastewater Treatment Plant before and after the reconstruction, it was estimated that $84,6 \%$ of total nitrogen and up to $97 \%$ of total phosphorus were removed by using the "BioBalance" technology, and Total-P and Total-N in the effluent were not higher than allowable norms.

2. Biological phosphorus removal was carried out efficiently, when the ratio $\mathrm{BOD}_{7} /$ Total-P is higher than 15 .

3 . The regressive correlation analysis shows the dependence of phosphorus concentration in the effluent on the ratio $\mathrm{BOD}_{7} /$ Total-P. The polynomial regression model is suitable for the obtained results. The model correlation in$\operatorname{dex} R^{2}=0,65$.

4. Effect of nitrates in the anaerobic zone on biological phosphorus removal was estimated. The experimental data show that nitrates in the anaerobic zone do not have a negative effect on biological phosphorus removal when the „Biobalance” technology is used.

5. The regressive correlation analysis shows the dependence of phosphate concentration in the aeration zone on nitrate concentration in the anaerobic zone. The polynomial regression model is suitable for the obtained results. The model correlation index is, respectively, $R^{2}=0,95$ and $R^{2}=0,94$ for the first and second aeration tanks.

\section{References}

1. Matuzevičius, A.; Paulauskienè, Z. Experimental investigation of phosphorus and nitrogen consumption and nitrogen removal from wastewater at a biological treatment plant. In: $3^{\text {rd }}$ International Conference. Cities Engineering and Environment. Vilnius: Technika, 1998. $137 \mathrm{p}$.

2. Harrison, R. M. Pollution: Causes, Effects and Control, Royal Society of Chemistry. 1993, 283 p.

3. Beržinskienè, J. Water microbiology: Textbook. Vilnius: Technika, 1999. 144 p.

4. Henze, M.; Harremoes, P.; Jansen, J. la C.; Arvin, C. E. Wasterwater Treatment. Biological and Chemical Processes. Springer-Verlag, 1995. $383 \mathrm{p}$.

5. Zhao, H. W.; Mavinic, D. S.; Oldham, W. K. and Koch, F. A. Factors affecting phosphorus removal in a two-stage intermittent aeration process treating domestic sewage. Water Science and Technology, Vol 38, No 1, 1998, p 115-122.

6. Siebritz, P.; Ekama, G. A. and Marais, G. v. R. A parametric model for biological excess phosphorus removal. Water Science and Technology, Vol 15, No 3-4, 1983, p 127-152.

7. Norgard, Peter; Helmo, Kim; Sorenser, Erik With. Purification process for nitroden removal controlled by NADH. Vand og Jord, Danish, Vol 3. 1996, p 126-129.

8. BioBalance. SymBio technology. 1996. 51 p.

9. Verlag für Architektur und technische Wissenschaften. Lehrund Handbuch der Abwassertechnik. Vereinigung, e.V., Berlin, 1995. $144 \mathrm{p}$.

10. BioBalance. On-line contact with biological processes. Wastewater purification. 1995. $14 \mathrm{p}$.

11. Martinènas, B. Statistical analysis of experimental data. Vilnius: Technika, 2004. 101 p.

12. Bundgaard, E.; Petersen, G. Methods for improving biological phosphorus removal. Kriiger, Copenhagen, Denmark, 1993. $148 \mathrm{p}$.

\section{BIOGENINIŲ MEDŽIAGŲ BIOLOGINIO ŠALINIMO IŠ NUOTEKŲ TYRIMAS}

\section{G. Vabolienè, A. B. Matuzevičius}

$\mathrm{S}$ a $\mathrm{n} \mathrm{tr}$ a u k a

Siekiant išvengti eutrofizacijos vandens telkiniuose, išleidžiant valytas nuotekas į uždarus ar mažai pratekančius vandens telkinius bei pakartotinai jas panaudojant kaip technologini vandenị, būtina šalinti azotą ir fosforą. Viena iš naujausių azoto ir fosforo šalinimo technologijų - „BioBalance“ technologija pritaikyta Utenos miesto nuotekų valymo įrenginiuose. Šalinant fosforą biologiniu būdu didelès itakos turi valomu nuoteku sudètis, ypač svarbu žinoti BDS B $_{7}$ BP santyki nuotekose po mechaninio valymo. Šalinant fosforą neigiamą poveiki gali daryti ir nitratai anaerobinejje zonoje. Todèl šių veiksnių poveikį biologiniams azoto ir fosforo šalinimo procesams labai svarbu ištirti.

Šiame darbe nagrinejjamas biologinio azoto ir fosforo šalinimo efektyvumas, taikant „BioBalance“ technologiją, Utenos nuotekų valymo irenginius rekonstravus. Taip pat nagrinejjamas aerotankų darbas: nustatyta priklausomybè tarp biocheminio deguonies sunaudojimo ir bendrojo fosforo santykio $\left(\mathrm{BDS}_{7} / \mathrm{BP}\right)$ nuotekose po mechaninio valymo ir bendrojo fosforo koncentracijos ištekančiose nuotekose bei priklausomybè tarp nitratų anaerobinejje kameroje ir fosforo šalinimo efektyvumo.

Raktažodžiai: biologinis azoto šalinimas, biologinis fosforo šalinimas, biologinis aktyvusis potencialas (BAP), biocheminio deguonies sunaudojimo ir bendrojo fosforo santykis $\left(\mathrm{BDS}_{7} / \mathrm{BP}\right)$, nitratai, fosfatai.

Giedrè VABOLIENĖ. Master, doctoral student, Dept of Water Supply and Management, Vilnius Gediminas Technical University (VGTU). E-mail: giedre.v@freemail.lt

Master of Science (water supply and management), VGTU, 1999. Doctoral student (environmental engineering and landscape management), VGTU, 2004. Publications: author of 3 research papers. Research interests: wastewater treatment.

Algirdas Bronislovas MATUZEVIČIUS. Dr, Assoc Prof and head of Dept of Water Supply and Management, Vilnius Gediminas Technical University (VGTU). E-mail: vk@ap.vtu.lt

Doctor of Science (hydraulic engineering), Kaunas Polytechnic Institute (KPI), 1970. Employment: Associate Professor and head of Department of Water Supply and Management, VGTU, since 1988. Associate Professor, Department of Water Supply and Sewage, KPI, 1974-1988. Publications: author of 42 research papers. Research interests: biological wastewater treatment, phosphorus and nitrogen removal from wastewater, sludge treatment. 